\title{
Effect of Silicafume on Properties of High Strength Concrete with Recycled Concrete Aggregate
}

\author{
Vignesh .G ${ }^{1}$, Dr. Selwyn Babu .J ${ }^{2}$ \\ ${ }^{1}$ Post Graduate Student, Department of Civil Engineering, PSNA College of Engineering \& Technology, Dindigul - 624622, Tamil Nadu, India \\ ${ }^{2}$ Assistant Professor, Department of Civil Engineering, PSNA College of Engineering \& Technology, Dindigul - 624622, Tamil Nadu, India
}

\begin{abstract}
Concrete is a widely used material in the construction world. In this experimental work, mechanical and durability properties of high-strength concrete containing different levels of silica fume with recycled concrete aggregate was studied. The work was focused on concrete Mix M60 having a fixed water/cement ratio of 0.33 and a constant total cement content of $518.18 \mathrm{~kg} / \mathrm{m}^{3}$. The percentages of silica fume that replaced cement in this research were: $0 \%, 2.5 \%, 5 \%, 7.5 \%$ and $10 \%$. The percentage of recycled concrete aggregate that replaced conventional aggregate in this research was 30\%.Apart from measuring the workability of fresh concrete, the mechanical properties such as: development of compressive strength on cubes, split tensile strength test on cylinders, flexural strength test on beams and young's modulus test on cylinders were evaluated. The durability properties such as: water absorption, porosity test and ultrasonic pulse velocity on cubes were evaluated. The results of this research indicate that as the proportion of silica fume increased, the workability of concrete decreased but its mechanical properties such as 28-day compressive strength, split tensile and flexural strength improved. The water absorption and porosity of recycled concrete aggregate and silica fume replaced mixes are lower than normal mix but within the permissible limit. The Ultrasonic pulse velocity was increased while adding of silica fume in concrete.
\end{abstract}

Keywords: High strength concrete, Silica fume, Recycled concrete aggregate, Compressive strength test and Flexural strength test

\section{Introduction}

Nowadays high-strength and high-performance concrete are widely used throughout the world and to produce them it is necessary to reduce the water/binder ratio and increase the binder content. Superplasticisers are used in these concretes to achieve the required workability; moreover, different kinds of cement replacement materials are usually added to them because a low porosity and permeability are desirable. Silica fume is the one of the most popular pozzolanas, whose addition to concrete mixtures results in lower porosity, permeability and bleeding because their oxides (SiO2) react with and consume calcium hydroxides, which are produced by the hydration of ordinary Portland cement. The main results of pozzolanic reactions are: lower heat liberation and strength development; lime-consuming activity; smaller pore size distribution.

The construction industry is using natural resources and disposing of construction and demolition wastes in very large quantities. The environmental and economic implications of both these practices are no longer considered sustainable. Many governments throughout the world are, therefore, promoting policies aimed at reducing the use of primary resources and increasing reuse and recycling. It is also acknowledged that recycling of demolition wastes for use as aggregate in new concrete offers an environmentally responsible and economically viable route to convert the material to a valuable resource

The suitability of recycled concrete aggregate (RCA) for use in normal grade concretes meeting requirements for various applications, namely foundations, paving, reinforced and prestressed concrete, has been examined by the author M.C. Limbachiya(7). This method was established for taking account of inherent RCA characteristics in the production of concrete that is stable in the fresh state and able to develop properties comparable to corresponding natural aggregate concrete in the hardened state. Furthermore, the work suggested that the use of coarse RCA may be extended to high strength concrete, thus offering further added value outlets for the material.

In high-strength concrete, which contains high quality and expensive materials, cracking provides the greatest concerns for the designers because harmful materials can penetrate from them to the concrete easily and start to destroy it and also corrode reinforcement. Some of these cracks are related to drying and autogenous shrinkage of concrete. Therefore, to improve the durability of high-strength concrete, its autogenous and drying shrinkage should be addressed and necessary work on its mixdesign should be done to minimize them. It is worth noting that autogenous shrinkage of concrete is because of chemical reactions during the hydration of cementitious materials; nevertheless, drying shrinkage occurs as a result of moisture movement from concrete to the atmosphere.This experimental investigation were compares strength and durability of high-strength concretes containing different levels of silica fume and partial replacement of recycled concrete aggregate.

\section{Literature Review}

J.J.Brooks et.al., (2000)(4) investigated that the setting times of the high-strength concrete were generally retarded when the mineral admixtures replaced part of the cement. Vahid Afroughsabet and Togay Ozbakkaloglu (2015)(5) investigated that addition of silica fume improves both mechanical and durability properties of high performance concrete. M. Mazloom, A.A.Ramezanianpour and J.J Brooks et.al., (2004)(6) investigated that the proportion of silica fume increased, the workability of concrete decreased but its short-term mechanical properties such as 28-day compressive strength and secant modulus improved. M. C. Limbachiya et.al., (2002)(7) investigated that up to $30 \%$ coarse RCA had no effect on concrete strength, but 


\section{International Journal of Science and Research (IJSR) \\ ISSN (Online): 2319-7064}

Index Copernicus Value (2013): 6.14 | Impact Factor (2015): 6.391

thereafter there was a gradual reduction as the RCA content increased.

\section{Materials and Mix propositions}

The cementitious materials used were ordinary Portland cement (OPC) and silica fume (SF). Locally available river sand. Crushed granite gravel with a nominal maximum size of $20 \mathrm{~mm}$ were used as the aggregates. Details of the mix proportions for the concrete containing different levels of silica fume are given in Table 1. The control mix was cast using OPC, while the other mixes were prepared by replacing part of the cement with silica fume at five different replacement levels on mass-for-mass basis. The percentage of recycled concrete aggregate that replaced conventional aggregate in this research was $30 \%$. The water/cement ratio and the slump of control high-strength concrete were 0.33 and $90 \pm 10 \mathrm{~mm}$, respectively. The same water/binder ratio of 0.33 was used for the other concrete mixes with the slightly reduction of slump. Consequently, the dosage of superplasticiser changed due to the effect of the different levels of silica fume. The super plasticizer used is based on Sulphonated Naphthalene Formaldehyde.

Table 1: Mix proportion of concrete containing different level of silica fume.

\begin{tabular}{|c|c|c|c|c|c|}
\hline $\begin{array}{c}\text { Cement } \\
\mathrm{Kg} / \mathrm{m}^{3}\end{array}$ & $\begin{array}{c}\text { Silica } \\
\text { fume } \\
\mathrm{Kg} / \mathrm{m}^{3}\end{array}$ & $\begin{array}{c}\text { Water } \\
\text { content } \\
\mathrm{Kg} / \mathrm{m}^{3}\end{array}$ & $\begin{array}{c}\text { Fine } \\
\text { aggregate } \\
\mathrm{Kg} / \mathrm{m}^{3}\end{array}$ & $\begin{array}{c}\text { Coarse } \\
\text { aggregate } \\
\mathrm{Kg} / \mathrm{m}^{3}\end{array}$ & $\begin{array}{c}\text { Water } \\
\text { cement } \\
\text { ratio }\end{array}$ \\
\hline 518.18 & 0 & 171.23 & 641 & 1122 & 0.33 \\
\hline 505.23 & 12.95 & 171.23 & 638.4 & 1122 & 0.33 \\
\hline 492.27 & 25.909 & 171.23 & 633 & 1122 & 0.33 \\
\hline 479.32 & 38.86 & 171.23 & 627.78 & 1122 & 0.33 \\
\hline 466.36 & 51.818 & 171.23 & 622.44 & 1122 & 0.33 \\
\hline
\end{tabular}

\section{Test Procedure}

\subsection{Compressive Strength Test}

The compressive strength of concrete cube was determined based on IS: 516-1959(2). The specimen was placed in the compressive testing machine in such a manner that the load applied should be to the opposite sides of the cubes as cast, that is not to the top and bottom. The compressive strength test is conducted in the compressive testing machine of $2000 \mathrm{kN}$ capacity. The specimen used was $100 \mathrm{~mm}$ x 100 $\mathrm{mm}$ cube. The test was performed at $7,14 \& 28$ days. The following figure (1) shows the compressive strength of cube and figure (2) shows the compressive strength results.

Table 2: Compressive strength of concrete

\begin{tabular}{|c|c|c|c|c|c|}
\hline Mix & $\begin{array}{c}\% \text { of silica } \\
\text { fume }\end{array}$ & $\begin{array}{c}\% \text { of recycled } \\
\text { concrete } \\
\text { aggregate }\end{array}$ & $\begin{array}{c}7 \text { days } \\
(\mathrm{MPa})\end{array}$ & $\begin{array}{c}14 \text { days } \\
(\mathrm{MPa})\end{array}$ & $\begin{array}{c}28 \text { days } \\
(\mathrm{MPa})\end{array}$ \\
\hline $\mathrm{M}_{1}$ & $0 \%$ & $30 \%$ & 35.73 & 46.33 & 54.33 \\
\hline $\mathrm{M}_{2}$ & $2.50 \%$ & $30 \%$ & 38.83 & 49.33 & 56.33 \\
\hline $\mathrm{M}_{3}$ & $5 \%$ & $30 \%$ & 39 & 50.33 & 56.67 \\
\hline $\mathrm{M}_{4}$ & $7.50 \%$ & $30 \%$ & 43.33 & 53 & 59.16 \\
\hline $\mathrm{M}_{5}$ & $10 \%$ & $30 \%$ & 43.67 & 54.23 & 61.16 \\
\hline
\end{tabular}

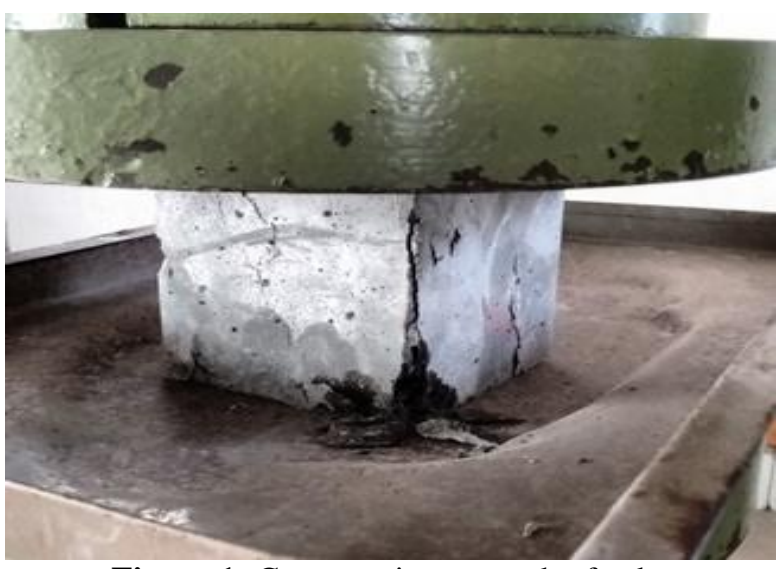

Figure 1: Compressive strength of cube

Figure 2: Compressive strength results

\subsection{Split Tensile Test}

The compressive loading tests on mortar cubes were carried out on a compression testing machine of capacity $2000 \mathrm{kN}$. For the split tensile strength test, a loading rate of $2.5 \mathrm{kN} / \mathrm{s}$ was applied as per IS: 516-1959(2). The specimen used was $150 \mathrm{~mm}$ diameter and $300 \mathrm{~mm}$ height. The test was performed at 28 days. The following figure (3) shows the split tensile strength of cylinder and figure (4) shows the split tensile strength results.

Table 3: Split tensile test of concrete

\begin{tabular}{|c|c|c|c|}
\hline Mix & $\begin{array}{c}\% \text { of silica } \\
\text { fume }\end{array}$ & $\begin{array}{c}\% \text { of recycled } \\
\text { concrete aggregate }\end{array}$ & $\begin{array}{c}28 \text { days } \\
(\mathrm{MPa})\end{array}$ \\
\hline $\mathrm{M}_{1}$ & $0 \%$ & $30 \%$ & 2.98 \\
\hline $\mathrm{M}_{2}$ & $2.5 \%$ & $30 \%$ & 3.16 \\
\hline $\mathrm{M}_{3}$ & $5 \%$ & $30 \%$ & 3.57 \\
\hline $\mathrm{M}_{4}$ & $7.5 \%$ & $30 \%$ & 3.77 \\
\hline $\mathrm{M}_{5}$ & $10 \%$ & $30 \%$ & 3.91 \\
\hline
\end{tabular}

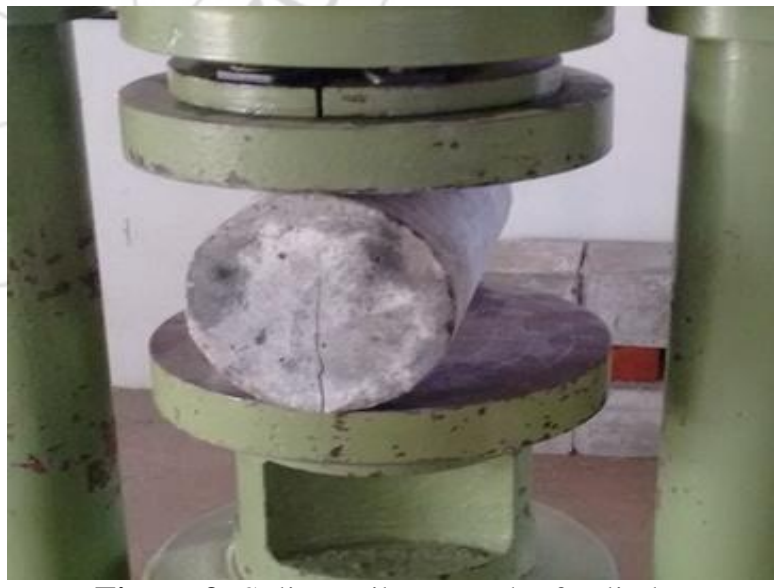

Figure 3: Split tensile strength of cylinder 
International Journal of Science and Research (IJSR)

ISSN (Online): 2319-7064

Index Copernicus Value (2013): 6.14 | Impact Factor (2015): 6.391

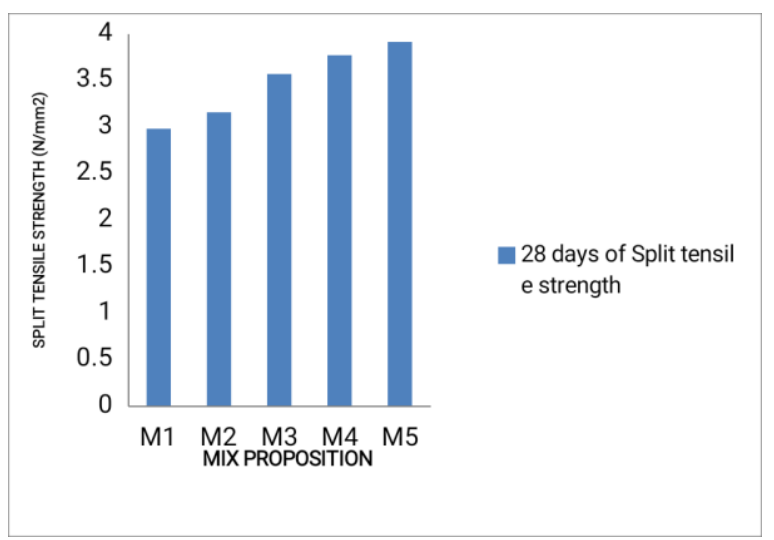

Figure 4: Split tensile strength results

\subsection{Flexural Strength}

Flexural strength test is done as per IS: 516-1959(2). Prisms are tested for flexure in Flexural testing machine of capacity $100 \mathrm{kN}$. The bearing surfaces of the supporting and loading rollers are wiped clean before loading. The prisms are placed in the machine in such a manner that the load is applied to the uppermost surface along the two lines spaced $13.3 \mathrm{~cm}$ apart. The axis of the specimen is aligned with the axis of the loading device. The load is applied at a rate of 180 $\mathrm{kg} / \mathrm{min}$ without shock. The specimen is loaded till it fails and the maximum load $(\mathrm{P})$ applied to the specimen during test is noted. After fracture the distance (a) between the crack and nearest support is measured. The flexural strength of the specimen is expressed as the modulus of rupture. The following figure (5) shows the flexural strength of prism and figure (6) shows the flexural strength results.

Table 4: Flexural strength of concrete

\begin{tabular}{|c|c|c|c|}
\hline Mox & $\begin{array}{c}\% \text { of silica } \\
\text { fume }\end{array}$ & $\begin{array}{c}\text { \% of recycled } \\
\text { concrete aggregate }\end{array}$ & $\begin{array}{c}28 \text { days } \\
(\mathrm{MPa})\end{array}$ \\
\hline $\mathrm{M}_{1}$ & $0 \%$ & $30 \%$ & 4.58 \\
\hline $\mathrm{M}_{2}$ & $2.5 \%$ & $30 \%$ & 5.34 \\
\hline $\mathrm{M}_{3}$ & $5 \%$ & $30 \%$ & 6.17 \\
\hline $\mathrm{M}_{4}$ & $7.5 \%$ & $30 \%$ & 7.67 \\
\hline $\mathrm{M}_{5}$ & $10 \%$ & $30 \%$ & 7.92 \\
\hline
\end{tabular}

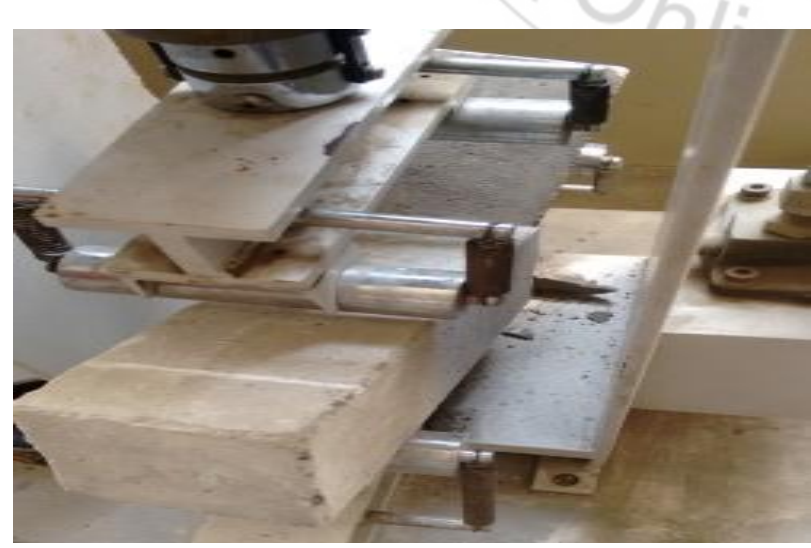

Figure 5: Flexural strength of prism

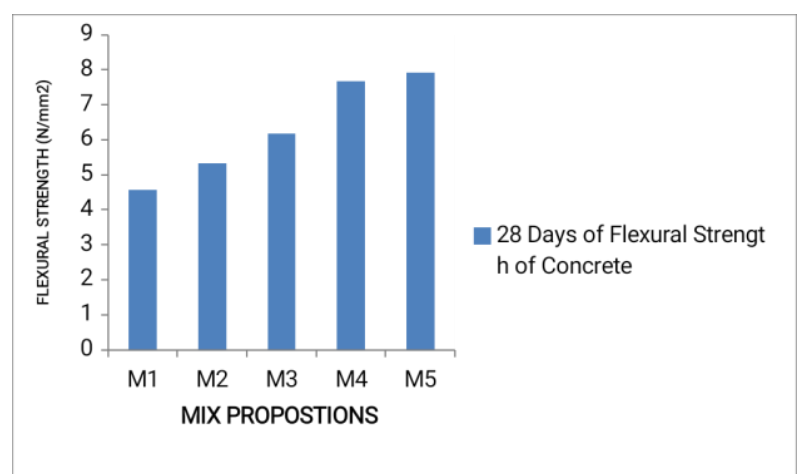

Figure 6: Flexural strength results

\subsection{Ultrasonic Pulse Velocity}

Ultrasonic stress (compression or shear) waves are produced by electro acoustic transducers made up of piezoelectric material. Transducers convert electric energy to the mechanical energy in form of stress wave which may be surface, compressive or shear waves. CANOPUS is shown in Fig 4 is used for UPV testing of specimens. Piezoelectric Transducers having $54 \mathrm{kHz}$ frequency are employed. As a coupling agent petroleum gel is used. Gel facilitates an airtight bond between concrete specimen and Transducers. The Testing Procedure is consisting of UPV test by Direct, Indirect and Semi-direct method at ages of 28 days interval. In Direct method, Transmitting and Receiving Transducers are kept on its opposite faces. While in Semi direct method, Transmitting and Receiving Transducers are kept on adjacent faces. And in Indirect method, Transducers are kept on the same face. The readings are taken by putting transmitter and receiving transducer on opposite faces in case of direct method. While In semi direct method, the readings are taken by putting transmitter on top and bottom faces sequentially and by varying receiver transducers on adjacent faces. In Indirect method, the receiving and transmitting Transducers are kept on same face with different interval. And it has been varied by $450 \mathrm{~mm}$ distance on same face. The following figure (7) shows the Ultrasonic pulse velocity instrument and direct method and figure (8) shows the ultrasonic pulse velocity results.

Table 5: Ultrasonic Pulse velocity of concrete

\begin{tabular}{|l|c|c|c|c|c|}
\hline Mix & $\begin{array}{c}\% \text { of } \\
\text { silica } \\
\text { fume }\end{array}$ & $\begin{array}{c}\% \text { of recycled } \\
\text { Concrete } \\
\text { aggregate }\end{array}$ & $\begin{array}{c}\text { Direct } \\
(28 \text { days }) \\
(\mu / \mathrm{s})\end{array}$ & $\begin{array}{c}\text { In direct } \\
(28 \text { days }) \\
(\mu / \mathrm{s})\end{array}$ & $\begin{array}{c}\text { Semi direct } \\
(28 \text { days }) \\
(\mu / \mathrm{s})\end{array}$ \\
\hline $\mathrm{M}_{1}$ & $0 \%$ & $30 \%$ & 3.3 & 1.90 & 1.92 \\
\hline $\mathrm{M}_{2}$ & $2.5 \%$ & $30 \%$ & 3.51 & 1.92 & 1.99 \\
\hline $\mathrm{M}_{3}$ & $5 \%$ & $30 \%$ & 3.58 & 1.96 & 2.06 \\
\hline $\mathrm{M}_{4}$ & $7.5 \%$ & $30 \%$ & 3.63 & 2.02 & 2.12 \\
\hline $\mathrm{M}_{5}$ & $10 \%$ & $30 \%$ & 3.79 & 2.10 & 2.20 \\
\hline
\end{tabular}




\section{International Journal of Science and Research (IJSR) \\ ISSN (Online): 2319-7064}

Index Copernicus Value (2013): 6.14 | Impact Factor (2015): 6.391

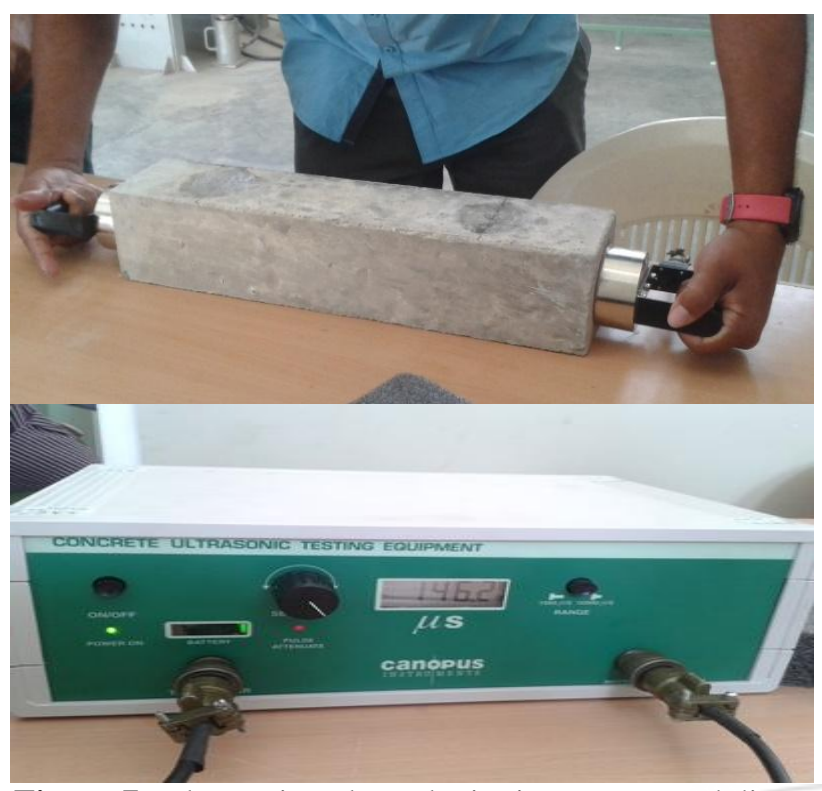

Figure 7: Ultrasonic pulse velocity instrument and direct method

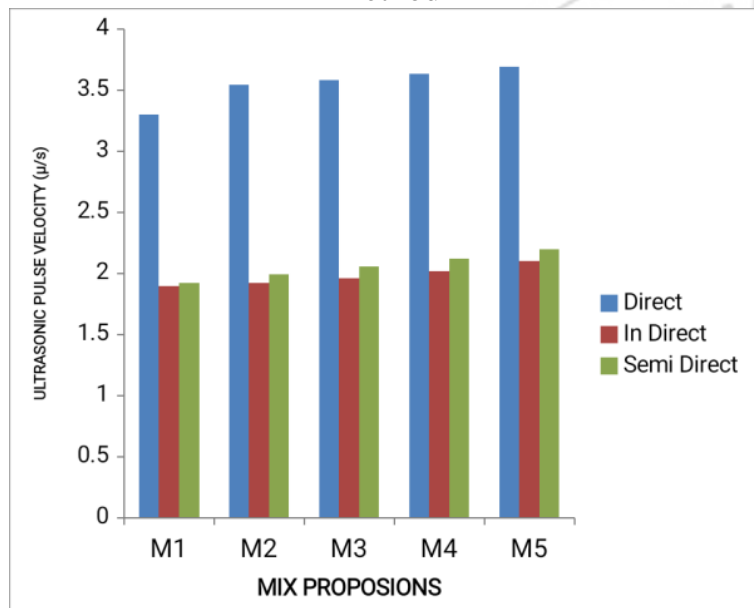

Figure 8: Ultrasonic pulse velocity results

\subsection{Water absorption test}

Water Absorption (WA) tests were carried out on $100 \mathrm{~mm}$ cube specimens at the age of 28 and 90 days curing as per ASTM C 642. The specimens were weighed before drying. The drying was carried out in a hot air oven at a temperature of 1050C. The drying process was continued, until the difference in mass between two successive measurements at 24 hours interval agreed closely. The dried specimens were cooled at room temperature and then immersed in water. The specimens were taken out at regular intervals of time, surface dried using a clean cloth and weighed. This process was continued till the weights became constant (fully saturated). The difference between the measured water saturated mass and oven dried mass expressed as a percentage of oven dry mass gives the water absorption. The following figure (9) shows the water absorption test results.
Table 6: Water absorption test for concrete

\begin{tabular}{|c|c|c|c|}
\hline Mix & $\begin{array}{c}\% \text { of } \\
\text { silica } \\
\text { fume }\end{array}$ & $\begin{array}{c}\% \text { of recycled } \\
\text { concrete } \\
\text { aggregate }\end{array}$ & $\begin{array}{c}\text { Water } \\
\text { absorption test } \\
28 \text { days }\end{array}$ \\
\hline $\mathrm{M}_{1}$ & $0 \%$ & $30 \%$ & 1.34 \\
\hline $\mathrm{M}_{2}$ & $2.5 \%$ & $30 \%$ & 1.31 \\
\hline $\mathrm{M}_{3}$ & $5 \%$ & $30 \%$ & 1.29 \\
\hline $\mathrm{M}_{4}$ & $7.5 \%$ & $30 \%$ & 1.25 \\
\hline $\mathrm{M}_{5}$ & $10 \%$ & $30 \%$ & 1.21 \\
\hline
\end{tabular}

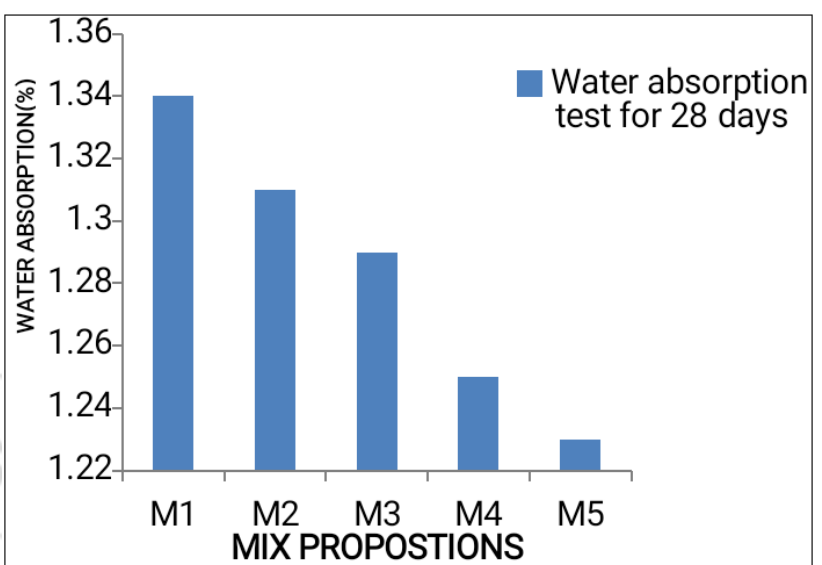

Figure 9: Water absorption test results

\subsection{Porosity Test}

The saturated water absorption of concrete is a measure of the pore volume or porosity in hardened concrete which is occupied by water in saturated condition. It denotes the quantity of water which can be removed on drying a saturated specimen. The porosity obtained from absorption tests is designated as effective porosity. It is determined using the following formula: Effective porosity $=($ Volume of voids/ bulk volume of specimen) x 100

The volume of voids is obtained from the volume of water absorbed by an oven dried specimen or the volume of water lost on oven drying water saturated specimen at $105 \mathrm{oC}$ to constant mass. The bulk volume of the specimen is given by the difference in mass of the specimen in air and it's mass under submerged condition in water. The following figure (10) shows the porosity test results.

Table 7: Porosity test for concrete

\begin{tabular}{|c|c|c|c|}
\hline Mix & $\begin{array}{c}\% \text { of } \\
\text { silica } \\
\text { fume }\end{array}$ & $\begin{array}{c}\text { \% of recycled } \\
\text { concrete } \\
\text { aggregate }\end{array}$ & $\begin{array}{c}\text { Porosity test } \\
28 \text { days }\end{array}$ \\
\hline $\mathrm{M}_{1}$ & $0 \%$ & $30 \%$ & 3.38 \\
\hline $\mathrm{M}_{2}$ & $2.5 \%$ & $30 \%$ & 3.31 \\
\hline $\mathrm{M}_{3}$ & $5 \%$ & $30 \%$ & 3.27 \\
\hline $\mathrm{M}_{4}$ & $7.5 \%$ & $30 \%$ & 3.25 \\
\hline $\mathrm{M}_{3}$ & $10 \%$ & $30 \%$ & 3.19 \\
\hline
\end{tabular}




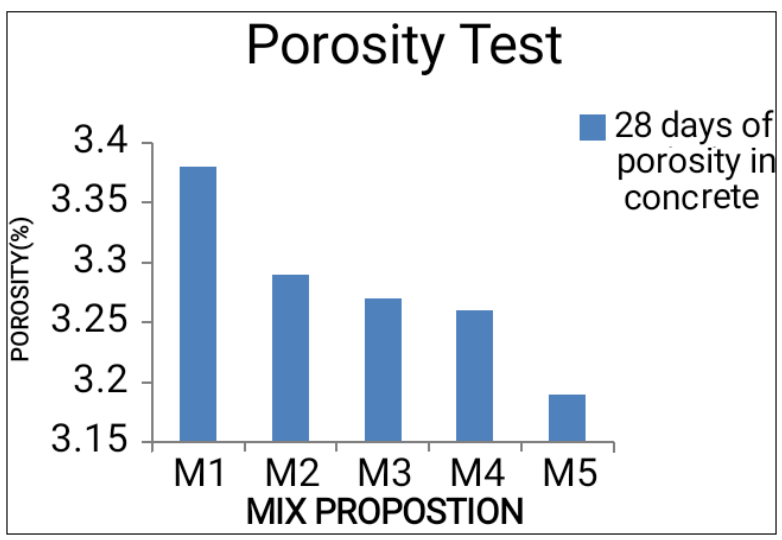

Figure 10: Porosity test results

\section{Results and Discussions}

An analysis was made on the strength characteristics by conducting the tests on High strength Concrete with Silica fume and Recycled concrete aggregate. In mechanical strength results were $10 \%$ of silica fume and $30 \%$ recycled concrete aggregate replacements gives more strength comparing to other percentage of replacements By comparing $(0 \% \mathrm{SF}$ to $10 \% \mathrm{SF})$ the compressive strength of concrete results at 28 days strength .It is observed that the strength of concrete is increase by 7.16MPa. By comparing $(0 \% \mathrm{SF}$ to $10 \% \mathrm{SF})$ the split tensile strength of concrete results at 28 days strength .It is observed that the strength of concrete is increase by $0.97 \mathrm{MPa}$. By comparing $(0 \% \mathrm{SF}$ to $10 \% \mathrm{SF}$ ) the flexural strength of concrete results at 28 days strength .It is observed that the strength of concrete is increase by $3.34 \mathrm{MPa}$. The result of ultrasonic pulse velocity were slightly increase the direct velocity with the permissible limit. The pulse velocity is (3-4.5), hence the concrete is of good quality. The water absorption and porosity of recycled concrete aggregate and silica fume replaced mixes are lower than normal mix. By comparing $(0 \% \mathrm{SF}-10 \% \mathrm{SF})$ the results of water absorption at 28 days. It is observed that the percentage of water absorption of concrete is decrease by $0.13 \%$. By comparing $(0 \%$ SF$10 \% \mathrm{SF}$ ) the results of porosity at 28 days. It is observed that the percentage of porosity of concrete is decrease by $0.19 \%$.

\section{Reference}

[1] ACI 211.4R-93 'Guide for Selecting Proportions for High-Strength Concrete with Portland Cement and Fly Ash', Reported by ACI Committee 211.

[2] Indian Standard Designation IS 516-1959, 'Methods of Test For Strength of Concrete' BIS, New Delhi, 2002.

[3] Indian Standard Designation IS 13311 (Part 1)- 1992, 'Methods of Non Destructive Testing of Concrete' BIS, New Delhi,2002

[4] Ramezanianpour .A.A, Mazloom .M and Brooks .J.J (2004) 'Effect of silica fume on mechanical properties of high-strength concrete', Cement \& Concrete Composites, Vol.26, pp.347-357.

[5] Vahid Afroughsabet .A and Togay Ozbakkaloglu (2015) 'Mechanical and durability properties of high-strength concrete containing steel and polypropylene fibers', Construction and Building Materials, Vol.94, pp.73-82.

[6] Brooks .J.J, Megat Johari .M.A and Mazloom.M(2000) 'Effect of admixtures on the setting times of highstrength concrete', Cement and Concrete Composites, Vol. 22, pp. 293-301.

[7] Limbachiya .M.C, Leelawat .T and Dhir.R.K(2000) 'Use of recycled concrete aggregate in high-strength concrete', Materials and Structures/Matiaux et Constructions, Vol. 3 , pp 574-580.

\section{Conclusion}

From the results presented in this paper, using concrete containing $0-10 \%$ silica fume and $30 \%$ Recycled concrete aggregate, the main conclusions are:

1) In concrete mixtures with a constant slump of $90 \pm 10$ $\mathrm{mm}$, those incorporating higher silica fume replacement levels tended to require more dosages of superplasticiser.

2) The results revealed that up to $10 \%$ replacement silica fume for cement and 30\% replacement Recycled concrete aggregate for Coarse aggregate in concrete shows improvement in Compressive strength, Tensile strength, Flexural strength, Ultrasonic pulse velocity and Decrease in water absorption \& porosity.

3) By comparing the results with Normal Mix ( $0 \%$ of silica fume $\& 30 \%$ of RCA) at 28 days, it is observed that the strength of concrete is increased when coarse aggregate is replaced beyond $30 \%$ of RCA and $10 \%$ silica fume.

4) From the results, it is observed that adding silica fume in concrete gives more strength than normal concrete mix. 